\title{
Great Salt Lake Exploration Platform
}

CHRIS TAYLOR

Texas Tech University

\section{ABSTRACT}

The Great Salt Lake Exploration Platform is a creative machine built to foster visual and performative research within the vastly under explored situated locale of the Great Salt Lake. GLSEP is a modular, flexibly deployable craft for a small group of people to remain upon the lake for limited durations of time, make work, and not die. Given the remote severity of this landscape the qualifier is significant. Storms appear quickly and can generate ten to twelve foot waves in tight oscillation. Coupled with the water's chemical density the lake is known to literally tear boats apart. Rather than being built and powered as a boat, with need of a marina to launch and a geometry to accommodate overland travel, the GSLEP is a deployable assembly providing necessary life support and research infrastructure (shade, fresh water, food and waste storage, solar power, communications, and evacuation provisions) to researchers operating on the Great Salt Lake, akin to off planet missions with immanent dangers and very limited rescue opportunities.

It can be difficult to imagine unexploited terrestrial sites for exploration. The remoteness of the Antarctic, Eurasian Steppe, and Sub-Saharan Africa have been rendered visible by the increasing ability of people with new media technologies to access and connect to once remote places. Despite the opportunity of new capabilities, much remains to be examined in our own backyards. The potency of primary research - first-person truth on the ground - remains paramount for architects, artists, and culture workers operating among the complex realities of the built environment. GSLEP initial test launch occurred in May 2015. The 2016 field season advanced operational knowledge and began the search for involvement from a wide range researchers from artists, architects, and writers to designers, scientists, and historians.

\section{ORIGIN}

Primary motivation to create the Great Salt Lake Exploration Platform began in 2005 when Matt Coolidge took Steve Badgett and Chris Taylor $^{1}$ for a drive on a bombing range south of Wendover, Utah. Venturing not for military engagement, but to examine brine collection canals of the Intrepid Potash company who extract minerals in large evaporation ponds by first collecting ground water through open canals extending for miles through the Great Salt Lake Desert. The idea emerged to consider building a craft, a salt boat, to allow people to work and spend time in these rarely visited canals. The project remained a stray possibility until 2012 when Badgett and Taylor assembled a grant proposal for the Graham Foundation for Advanced Studies in the Fine Arts. The application coalesced our interests within the basin of the Great Salt Lake. News of the award meant the proposition had to evolve from possibility to actuality. Shortly after the Graham funding a Creative Arts, Humanities, and Social Sciences Research Award for the project was received from Texas Tech University. $^{2}$

\section{CREATIVE MACHINES}

The Center for Land Use Interpretation (CLUI), SIMPARCH, and Land Arts of the American West at Texas Tech University are creative machine authoring works that produce other works to propel the actions of others. The Center for Land Use Interpretation, formed in 1994, creates exhibitions, public programs and projects, that explore "the nature and extent of human interaction with the surface of the earth, and in finding new meanings in the intentional and incidental forms that we individually and collectively create." ${ }^{3}$ SIMPARCH is an art collaborative founded by Steve Badgett and Matt Lynch in 1996. While operating within the arena of visual art SIMPARCH makes legible propositions of visionary futures, energy horizons, and cultural aspiration. DYI directness drives an aesthetic and conceptual ethos manifest in the fabrication and trajectory of their work. ${ }^{4}$ Land Arts of the American West at Texas Tech University began in 2008 as a "semester long transdisciplinary field program expanding the definition of land art through direct experience with the full range of human interventions in the landscape... Land Arts investigates the intersection of geomorphology and human construction beginning with the land and extending through the complex social and ecological processes that produce contemporary landscapes. It is a 


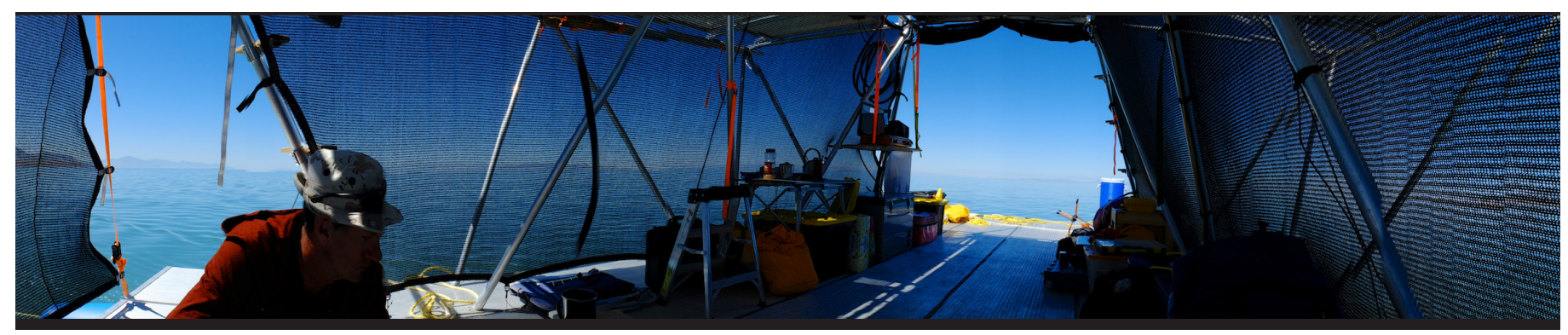

Figure 1: Within the Great Salt Lake Exploration Platform off Antelope Island, Utah, 17 June 2016. Photograph by Chris Taylor.

semester abroad in our own back yard where each fall students venture across the American southwest camping for a two months while traveling six-thousand miles overland." ${ }^{5}$ The opportunity of GSLEP emerges from the interactions between Coolidge, Badgett and Taylor and their collective desire to expand thresholds of awareness and capacity for people to operate in under examined landscapes. CLUI is the operational beneficiary of GSLEP and will solicit, organize, and manage resident projects. ${ }^{6}$

The late science fiction writer J.G. Ballard focused on what might happen within his immediate surroundings in the next 15 minutes. Ballard's articulation of the possibilities within the immediate now, directs attention to the under explored landscapes within our field of view rather than in some far off land.

\section{CONDITION}

The Great Salt Lake Desert is North America's backyard collecting landuses, building programs, and expounding material history expelled from other parts of the United States. The Great Salt Lake is the lowest portion of this desert and a remnant of prehistoric Lake Bonneville. It has no drain. It's an "entropic sink." A terminal landscape. Slowly grinding everything to geologic flatness of silt and salt. As a fundamentally inhospitable landscape (no fish live there), the Great Salt Lake holds unique and extreme architectural challenges for even temporary occupation. Robert Smithson made such challenges visible by including the following passage in his film Spiral Jetty (1970): "the notion that the lake must be connected to the Pacific Ocean, by subterranean channel at the head of which a huge whirlpool threatened the safety of the lake craft, was not dispelled until 1870's long after people should've known better. As a matter of fact, 'eyewitnesses' reported the location of the whirlpool about midway between Fremont and Antelope Islands." ${ }^{\prime 8}$

Yet the Great Salt Lake is more complex than geology and myth. It is essentially two bodies of water divided by a rail line called the Lucin Cutoff first built on an open wood trestle in the early 1900s and filled solid with gravel in the late 1950s. While narrow cuts through the causeway attempted to allow lake levels to balance, the earthen structure created two distinct ecologies between the northern and southern arms. The majority of fresh water inflows to the southern portion, which runs three to five times saltier than sea water carrying a greenish appearance. Microscopic halophilic bacteria thrive in the super saline saturated northern arm giving the water its milky red cast - a key trait that attracted Robert Smithson to build Spiral Jetty. Currently an effort is underway to construct a new 180 foot bridge to breach the causeway and allow lake levels and chemistry to balance. ${ }^{9}$ Given the shallow geomorphology of the basin, changes in the quantity of water entering profoundly impact lake size, shoreline location and chemical composition.

\section{EXPERIMENTATION}

As work on GSLEP began we sought experience from people working on the lake such as visiting with a brine shrimper who relayed stories of massive waves generated in the middle of the lake by storms. During the winter shrimping season he was alone in a spotting vessel when sustained wave impacts flattened the hull of his boat within seconds. Fortunately he was able to issue a Mayday radio call and forty-five later minutes he was rescued from the twenty-eight degree water - lucky to have survived. Beyond the obvious design imperative of avoiding being on the lake in February his story made real a set of serious design issues. The forces of the lake are too great for us to fight directly. Our design had to embrace engineered performance and operational anticipation to avoid catastrophe. The Great Salt Lake Marina harbor master has told us directly, numerous times, that he has navigated waters all over the world and this lake is the least predictable and most dangerous body of water he has experienced. Going on to say that people who are cavalier about the elements usually find themselves in dire trouble. With contemporary narratives reinforcing historical accounts of lake conditions we began a design process that could not rely on precedent or prototype. We adopted a design ethos akin to off planet missions, attempting to anticipate the difficulty or near impossibility of rescue. Our approach had to include provisions for survival and self sustenance with aspirational references ranging from Ciudad Abierta venturing by sea to Patagonia thru the Pacific Northwest to outer space, examining the hydrofoils by Alexander Graham Bell and Dymaxion logics of Buckminster Fuller. ${ }^{10}$

The fundamental design goal of our craft was to allow a small group of people to remain upon the lake for limited durations of time, make work, and not die. Given the remote severity of this landscape the final qualifier is significant. The other essential design imperative was to create a modularly deployable platform that could enter the lake from any point, without the aid of a marina, so the entire structure had to be demountable into components that a few people could carry or cart from road to water.

The design process began with small tests of various forms and by investigating electric propulsion systems. To operate with solar power the roof area has a direct impact on the amount of electricity we can generate. The German made Torqeedo motor we acquired draws 2,000 watts at full load, so that set the base for the amount 


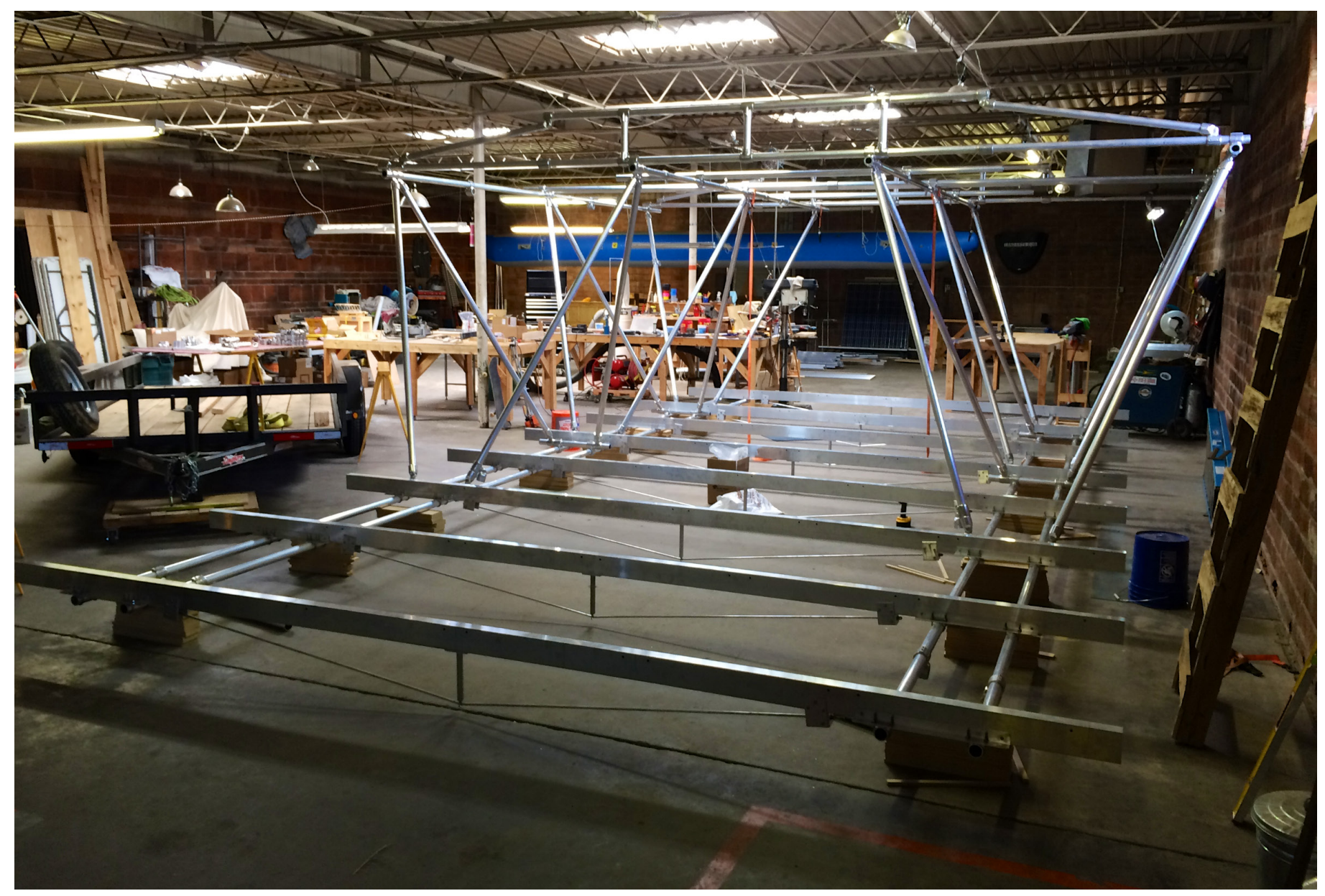

Figure 2: Fabricating GSLEP, Lubbock, Texas 1 May 2015.

Photograph by Chris Taylor.

of incoming power. We hoped in normal or ideal conditions we would be able to sync our power consumption with the levels of incoming solar energy thereby keeping the batteries at full charge for emergency use. While study models were expanding evolutionary thinking about structure and performance, the design process evolved in the workshop through key decisions and acquisitions impacting the project. Email between Badgett and Taylor often contained images of sketches, mock-ups or models to make legible the question of how the platform would be built. In the end it became essential that the design and evolution be as flexible as possible. So rather than creating custom welded connectors for the aluminum pipe framework speed-rail fittings were chosen that can be easily reconfigured should design intentions fail. The platform required structural integrity to withstand the hazards of the lake. Micro weather forces can produce abrupt changes in wind speeds generating significant wave action. We kept reminding ourselves that this lake is known for tearing boats apart.

\section{FABRICATION}

Full speed fabrication began in April of 2015 when Badgett arrived at the Architecture Workers Combine in Lubbock, Texas. As materials and components arrived two months were spent moving from design possibilities to actualities of fabrication by assembling, testing, and constantly retooling the primary framing of the sixteen foot by thirtyfour foot platform. Custom twenty-eight inch diameter inflatable pontoons provided our buoyancy. Above the floor trusses and aluminum decking rose the pipe structure in an attempt to create a rigid framework to withstand wave action, wind, and support live loads.

In addition to fabricating the platform itself the attending infrastructure had to be incorporated. From the power generation and propulsion systems to modes of transport to the lake and across the highly variable lake bed. This included modifications to a standard sixteen foot utility trailer and the creation of an overland haul cart.

\section{EMBARKATION}

With fabrication efforts barely complete it was time to disassemble the working structure in the shop, load it onto the trailer, and make the voyage across the continental divide and into the Great Salt Lake Desert. We arrived Rozel Point on the northern arm of the lake in fading light and established a base camp at the end of the oil exploration jetty just south of Spiral Jetty. This was the staging location for unloading the trailer and hauling the 2,500+ pounds of components and gear to the waters edge. With the lake at historic low levels the water was about three-quarters of a mile from the staging camp. Everything needed to assemble and deploy the platform had to make the journey, to be schlep'ed across the mud and salt flats to the water. 


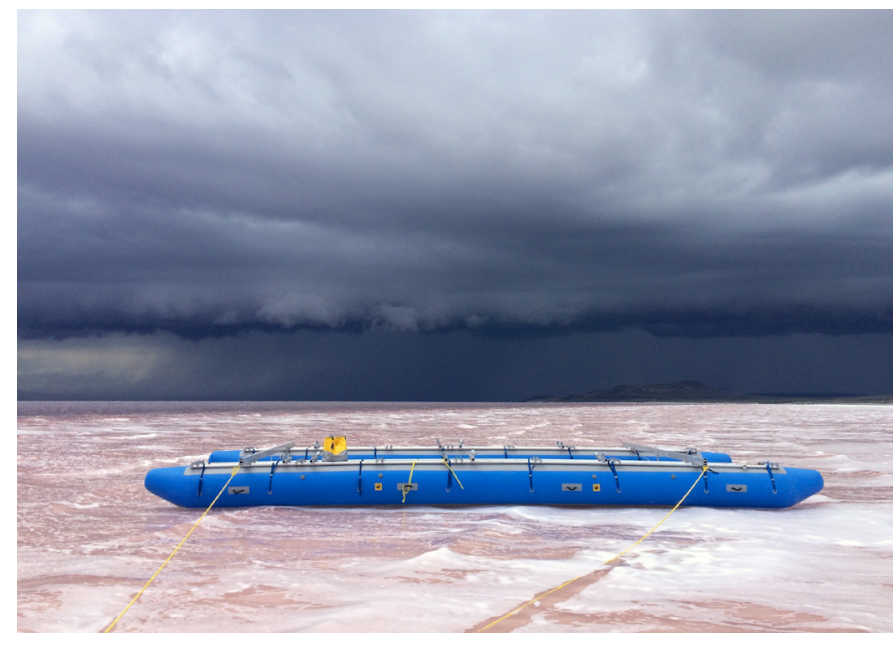

Figure 3: GSLEP field assembly, Rozel Point, Utah, 26 May 2015. Photograph by Chris Taylor.

This is were the aggregation of component assemblies was tested. The haul cart proved essential for hailing, tubes, panels, parts, and even people. We tried to keep loads under four hundred pounds.

The water provides a level assembly surface - a big table - and facilitates movement through floatation. Yet we learned quickly that the lake is only flat when the wind is still and the wind produces a range of curious effects. Such as whipping up foam from the saline saturated water. On the northern arm the water is essential at saturation. It can hold no additional salt, so the minerals precipitate out onto the lake bed creating a solid, dense, lens of salt as lakebed.

This is truly a surreal landscape - a primary reason Robert Smithson chose this place to build Spiral Jetty comes from the otherworldliness of its pink water. Kooky water. Expansive skies. Big weather. The weather is actually a major concern. We continued to remind ourselves of the people who told us of storms kicking up ten to twelve foot waves in the middle of the lake. Our platform is only partially suited for the extremities of this environment. After all it is built on inflatable pontoons. The truss work is an effort to create a unified frame should we get caught in the midst of a storm. Our biggest fear, besides a pontoon puncture, is being surprised by a big weather system and being blown to the other side of the lake. Our motor is suited for ideal panning speed, not ramming speed, or fighting $50 \mathrm{mph}$ winds. If we are blown across the lake, just because we make land fall doesn't mean we'll live. It can be miles and miles of exposed and open country until the nearest road or ranch.

While the conditions can turn dire, the lake is also transcendental. The sky often being as active as the water, singing, or vibrating with color. We set out on our first motor test as soon as the frame is in place, eager to test the propulsion. Part of the enthusiasm fueled by the magnetic horizon. The crew of the first test launch included: Matt Coolidge, director of the Center for Land Use Interpretation; Marie Lorenze, an artist based in New York who created the tide water taxi and plans to use the platform in a project; Steve Badgett, SIMPACH member; Deborah Stratman, an artist who creates documentary films; curator Ingrid Schaffner and myself. Our initial test was fairly productive. The platform floated-even with several people on board. It generated as much power as used. All told the schlep and multi-day assembly was fairly smooth for a first time out.

As quickly as we appeared it was time to disassemble, load up and leave the lake. Disassembly was considerably quicker. From the lake all components came back to the CLUI base in Wendover where they were unpacked and completely cleaned to remove as much salt as possible. Salt permeates everything after spending a week on the lake. Once clean and repacked the platform overwintered in a former bomb assembly building leased by CLUI.

\section{REFLECTION}

Hopefully the sense of GSLEP as an instrument is becoming clear. It is vehicle, literally, for putting people out in this very particular and under explored landscape. No fish live in this water. Very, very few people venture into the north part of the lake. Repeat, no fish live here. The water is magic. Part of the danger, and the beauty, of the Great Salt Lake Desert is how possible it is to become lost between the sky and ground. This is particularly true when on the water. It is as if we are in suspended animation, emerging from a dark and mysterious place. And we are. We consider the platform as a literal stage for people to do their work. Imagine choreographing a dance here, a theatrical performance, there are significant potentials for how the platform can be deployed with its modular fabrication. This is a place to imagine alternate futures from new readings from of the world we find ourselves within. ${ }^{11}$

The platform continues to become enmeshed in expanding cultural conversations. During the summer of 2016 the project was included in the exhibition "Radical Seafaring"12 at the Parrish Art Museum along side works by Bas Jan Ader, Ant Farm, R. Buckminster Fuller, Marie Lorenz, Mary Mattingly, Dennis Oppenheim, Robert Smithson, Simon Starling, and Swoon, among others.

\section{POSITION}

In May of 2016 Badgett, Coolidge and Taylor met again to return to the lake for more sustained testing of the platform. CLUI began an open call for research proposals this year to examine the lake, particularly the northern arm, selected researchers will engage the lake and platform in ways specific to their project. ${ }^{13}$ The 2016 field season did not require direct use as base systems of operability continue to be tested and fine tuned. Ongoing development includes: platform performance in diverse weather conditions, power and motor system range and functionality, and general life support infrastructure. A few 2016 improvements are: an emergency shelter for waiting out a storm on shore, lightning suppression system, moveable shade panels to allow variable levels of enclosure in response to use and conditions, backup motor and inflatable launch for towing or escape.

Ongoing state permit processing to operate on the lake bed caused the location of our logistical operations base for the 2016 season to shift to the southern arm at the Antelope Island Marina. The basic workflow remained consistent with assembling platform at waters edge - albeit with a much shorter schlep. Having more time on the water to test the 


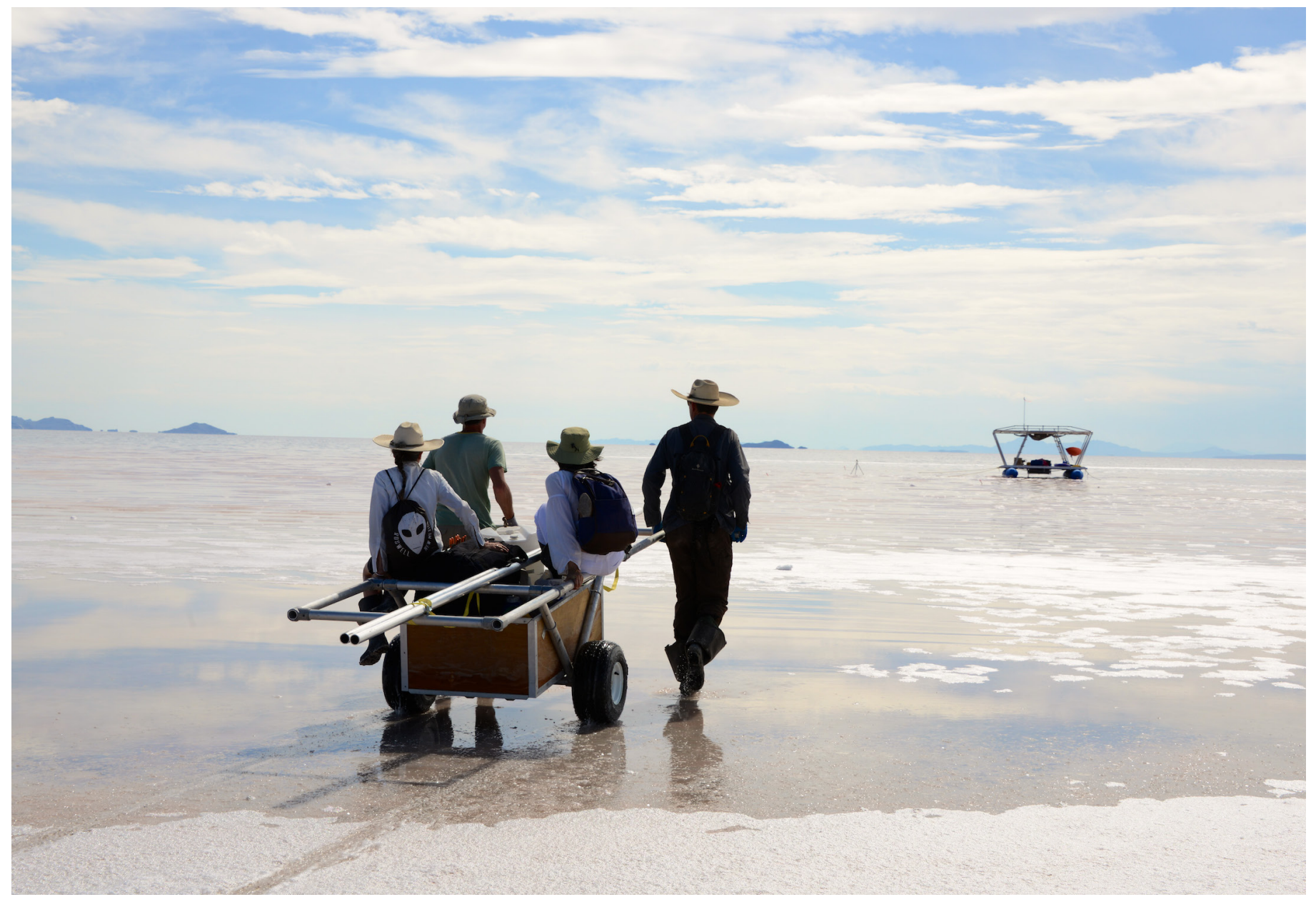

Figure 4: Hauling gear and people towards GSLEP, Rozel Point, Utah, 30 May 2015. Photograph by Center for Land Use Interpretation.

limits and opportunities of the power system was the vital lesson of this years cycle. The venture towards the horizon allowed the propulsion system to be more fully tested. The intended approach allowing for the control of how much power is used relative to what can be made from the sun with the photovoltaic panels seeks to keep the battery bank charged. Testing that theory we found, among other things, the system worked. The biggest travel day thus far covered approximately twentyeight miles to approach the Lucin Cutoff, averaging about three miles per hour. We are also learning what happens when the wind kicks up and the sun goes down. Fortunately we were able to moor overnight at the Trestlewood Marina next to an oil saturated, rusting hulk of an old tug. Power consumption and structural integrity remain the primary forces, and limits, we continue to examine as our understanding of the platform and its operation evolves. It all hinges on wind.

\section{PROJECTION}

Next steps for GSLEP include continuing to build out infrastructural fixtures (storage, kitchen, work surfaces) and streamline operational knowledge (assembly, use, disassembly). Creating an instruction manual for residents will be helpful and lead into future publication efforts. We plan to document the use and deployment of the craft through several resident projects to study how GSLEP adapts and evolves over time. Documentation of this architectural and cultural adaptation is of particular interest. CLUI will continue to cultivate and manage resident project with Badgett and Taylor operating as crew and constructors of this evolving experiment.

The central ethos of the Great Salt Lake Exploration Platform is how it operates as an instrument. A vehicle. Focusing attention beyond, or even through, itself to the landscape we occupy. In the end this is less about the form of what we have made, and more about an architecture that propels interaction with places - as a creative machine operating within the extreme territory of the Great Salt Lake. 


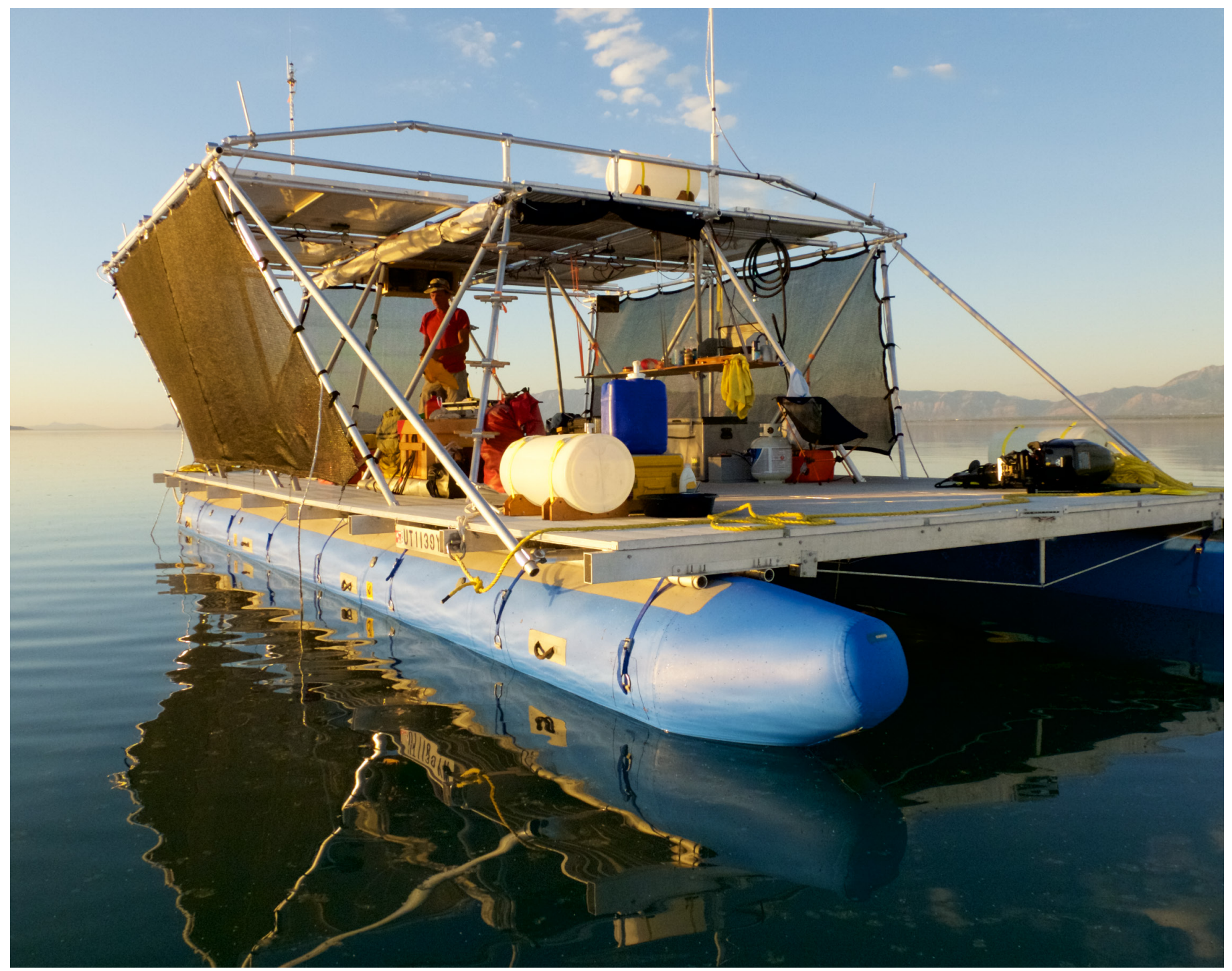

Figure 5: GSLEP off Antelope Island, Utah, 22 June 2016. Photograph by Chris Taylor. 


\section{ENDNOTES}

1. Coolidge is the director of the Center for Land Use Interpretation, Badgett is a member of the art collaborative SIMPARCH, and Taylor is the director of Land Arts of the American West at Texas Tech. See: Coolidge, Matthew and Sarah Simons (eds). Overlook : exploring the internal fringes of America with the Center for Land Use Interpretation. New York: Metropolis Books, 2006. Rowell, Steve, Antonio Castro, Kate Bonansinga, Ben Nicholson, and SIMPARCH. Hydromancy: SIMPARCH with Steve Rowell. El Paso, Texas: Stanlee and Gerald Rubin Center for the Visual Arts, 2007. Wood, Catherine. SIMPARCH. London: Tate Modern, 2005. Taylor, Chris and Bill Gilbert. Land Arts of the American West. Austin: University of Texas Press, 2009.

2. With both grants, the total budget for the project was just under thirty thousand dollars.

3. From <clui.org > accessed 21 July 2016

4. See <simparch.org $>$ for additional information.

5. From <landarts.org/category/program/> accessed 21 July 2016.

6. See Wendover Interpretive Research Program for additional information <www.clui.org/section/wendover-interpretive-research-programs-2016-2017>

7. Ballard, J.G.. The Best Short Stories of J.G. Ballard. New York: Picador, 1978.

8. Utah Geological Society. Guidebook to the Geology of Utah. Salt Lake City: Utah Geological Society, 1946-1970.

9. From <www.up.com/aboutup/community/inside_track/causeway-6-14-2016> accessed 21 July 2016

10. Ivelic, Boris K. Embaracaión Amereida y la épica de fundar el mar Patagónico. Valparaíso, Chile: Escuela de Arquitectura y Diseño, Pontificia Universidad Católica de Valparaíso, 2005. Brower, Kenneth. The Starship and the Canoe. New York: Holt Rinehart \& Winston, 1978. Blush, BJ and SR McNeal. Update on Space. Granada Hills, Calif. : National Behavior Systems, 1981. Lebedev, VV, Daniel Puckett and CW Harrison. Diary of a Cosmonaut: 211 days in space. College Station, Texas: PhytoResource Research, Information Service, 1988. Bruce, Robert V. Bell: Alexander Graham Bell and the Conquest of Solitude. Boston: Little Brown, 197. Fuller, R Buckminster, Joachim Krausse and Claude Lichtenstein. Your Private Sky: $R$. Buckminster Fuller, the art of design science. Baden: Lars Müller, 1999.

11. Lopez, Barry. The rediscovery of North America. Lexington, Kentucky: University Press of Kentucky, 1990.

12. Andrea Grover, Parrish Art Museum. Radical Seafaring. Munich: Delmonico Books, Prestel, 2016.

13 In 2016 CLUI selected five resident projects from a group of over forty to work out of the Wendover facility and examine topics relating to the Great Salt Lake. 